\title{
The Road Less Traveled By
}

\author{
Julie S. Vargas \\ West Virginia University
}

\author{
I shall be telling this with a sigh \\ Somewhere ages and ages hence: \\ Two roads diverged in a wood, and I- \\ I took the one less traveled by, \\ And that has made all the difference. ${ }^{1}$
}

This year the Association for Behavior Analysis (ABA) held its fifteenth convention. We have come a long way from the hectic days of the first conference, when students at Western Michigan University put together the program book-at the very last minute. Margaret Vaughan (then Peterson) described the final assembling of the program this way:

Mertens [who had coordinated submissions] called me at around 10:00 p.m. to read over the phone the entire three day schedule. This meant writing down first author, and sometimes second, third, and fourth; affiliations of each; and the paper, symposia, workshop, or conversation hour title. At approximately 1:00 a.m., unable to write any further, I convinced another graduate student at Western to finish the task. (Peterson, 1978, p. 6)

The next day, students called 70 speakers to confirm the information, and over that day typed the entire program book. ABA still runs primarily through volunteer help, but the organization now has a paid staff, and it has been many years since anyone worried whether the program book would be printed in time for the convention.

Now, as ABA has entered its teenage years, it has begun to look at itself and its operations. Barbara Etzel, in her first "Message from the President" (Etzel, 1987) stated a concern that ABA mem-

This article was presented as the presidential address at the May 1989 convention of the Association for Behavior Analysis in Milwaukee. I wish to thank Ernest A. Vargas and Donald Cook for their suggestions on earlier versions of the manuscript. Send reprint requests to Julie S. Vargas, Box 6122, West Virginia University, Morgantown, WV 26506.

' From THE POETRY OF ROBERT FROST edited by Edward Connery Latham. Copyright 1916, (c) 1969 by Holt, Rinehart and Winston. Copyright 1944 by Robert Frost. Reprinted by arrangement with Henry Holt and Company, Inc. bers had communicated to her: "Council seemed to be distancing itself from the membership." During 1988, Etzel and Morris published articles discussing ABA's mission and structure (Etzel, 1988; Morris, 1988). At the May 1989 conference, Council discussed a reorganization model proposed by Iwata. This paper adds to ABA's introspection, after briefly reviewing $A B A$ 's roots and outlining its present status.

\section{ROOTS}

The Association for Behavior Analysis grew out of a two-day conference on the Experimental Analysis of Behavior held in 1974 at the University of Chicago. ${ }^{2}$ The participants were psychologists, members of the Midwestern Psychological Association who were dissatisfied with the representation of behavioral papers within that organization. The group originally named itself the Midwestern Analysis of Behavior Association, or MABA. It decided to meet the next year concurrently with the Midwestern Psychological Association in May 1975. A team of students and faculty at Western Michigan planned a session, expecting about 200 people. Nearly 1,000 came.

After much debate, MABA separated from the Midwestern Psychological Association over the 1975-76 academic year. The decision was aided by data indicating that few members of MABA attended the regional psychological meetings, by a lack of hotel space during the MPA's planned time, and finally by an action of the Midwestern Psychological Association itself. MPA rejected MA-

\footnotetext{
${ }^{2}$ Information on the early history of the organization is taken from Peterson (1978).
} 


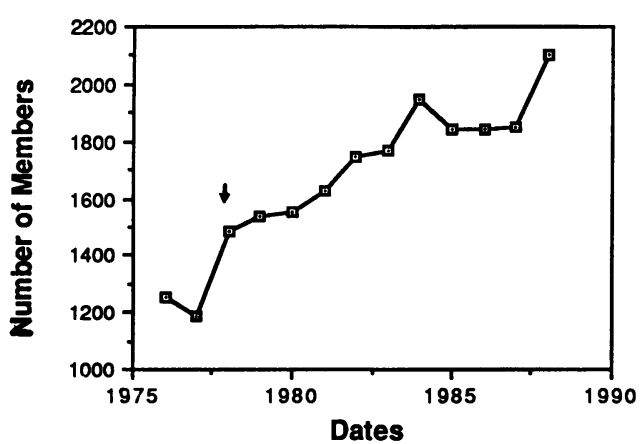

Figure 1. Membership in the Association for Behavior Analysis. Arrow shows the year in which The Behavior Analyst began publication.

BA's request for "joint session status." MABA's coordinator and one of the most active individuals in its early forming (Gerald Mertens) resigned over the decision to leave MPA. Others were also unhappy about the split, but MABA began the process of incorporating as an independent organization in fall of 1975. During the following spring, funds were raised and a convention was planned. By May 1976, MABA was an established fact.

Conferences were a critical part of MABA's birth, and the "open forum" and "information exchange" functions figure prominently in the initial goals statement:

1) To promote the continuing development of experimental and applied analysis of behavior;

2) To promote the acquisition of information needed to apply behavioral principles;

3) To promote education for those desirous of using behavoral techniques in appropriate settings;

4) To provide an opportunity for experimentation, discussion, and consensus before public statements are rendered on issues of recognized mutual concern;

5) To encourage research by its members; and

6) To promote the concept of an open forum for information exchange.

Advocacy functions do not figure as strongly, but they are present in the word "promote" and in the concern for consensus about public statements.

In line with its goals, most of MABA's early efforts revolved around the yearly conference. The organization sent out a newsletter, and talked of a journal. In the spring of 1978, the first issue of The Be- havior Analyst came out under the editorship of Scott Wood. Following the educational mission of the organization, Council decided to send the journal to all members of MABA.

MABA grew slowly but steadily, adding about 100 members each year (Figure 1). Individuals from all over the United States and from foreign countries began joining. To reflect this new representation, in 1979 MABA dropped the regional part of its name. It became ABA, the Association for Behavior Analysis: An International Organization.

With the journal and the broadening of membership, ABA's activities spread beyond the Midwest. Special interest groups began to form. Regional and foreign chapters of ABA developed. At the same time, Council formed committees to accomplish ABA business. The grass roots activities of the local groups did not always mesh well with the top-down leadership of Council and its committees and task forces. They did not clash, exactly; rather the groups tended to ignore each other, resulting in duplication of effort. For example, ABA members in Florida were working with their State Department of Health and Rehabilitative Services/Developmental Services to develop a credentialing exam for behavior analysts at the same time that a Council committee was working on certification. Another example: When Council appointed a task force called "Right to Effective Education," the group began work without involving the Special Interest Group in Education. In short, no mechanism existed, or exists today, to coordinate the activities of special interest groups, of chapters, and of committees and task forces. Yet each is a vital part of ABA.

\section{ACTIVE GROUPS WITHIN ABA}

\section{Special Interest Groups}

Special interest groups begin when a few members propose a name and request a meeting time and place at the convention. Those who attend the session elect officers and, if there is sufficient interest, submit an application for official 
Table 1

Special Interest Groups

\begin{tabular}{lccc}
\hline \multicolumn{1}{c}{ Name } & $\begin{array}{c}\text { Years listed } \\
\text { in program }\end{array}$ & $\begin{array}{c}\text { Sends out } \\
\text { newsletter }\end{array}$ & $\begin{array}{c}\text { Recent } \\
\text { numbers }\end{array}$ \\
\hline Behaviorists for Social Action & $77-$ & Yes & 161 \\
Behavior Analysts in Education & $79-$ & Yes & 21 \\
Clinical Behavior Analysis & $81-$ & Yes & 36 \\
Computer Users & $81-$ & & \\
Direct Instruction & $81-$ & & 122 \\
Behavioral Residential Treatment & $82-85$ & & 103 \\
Behaviorism as a way of life & $82-82$ & & 135 \\
Behavioral Gerontology & $82-$ & & 503 \\
Ethical and Legal Issues & $82-$ & Yes & 101 \\
Pharmacology & $82-83$ & Yes & \\
OBM Network & $82-*$ & Yes & 12 \\
Verbal Behavior & $82-$ & Yes & \\
Experimental Analysis of Human Behavior & $83-$ & & \\
JABA Users Group & $84-$ & $85-$ & \\
Interbehaviorists in ABA & $88-$ & & \\
Correctional Behavior Analysis & $88-$ & & \\
Rehabilitation \& Independent Living & & &
\end{tabular}

* Except for 1986.

"special interest group" status. Funds for activities are solicited from members. The bylaws of $\mathrm{ABA}$ prohibit $\mathrm{ABA}$ funds to go to special interest groups. Other than filing reports to Council, and interacting with ABA's central staff on convention activities, special interest groups function independently of ABA's central government, even on paper. In fact, the relationship is even more tenuous than one would expect from the listing of special interest groups in the newsletter and convention programs. Council has not called upon special interest groups to help with Council projects, and the special interest groups are somewhat cavalier about sending in reports of their activities. The ABA central office files contain only about half of the reports that should be there, and most of those are not complete. The lack of reports does not, however, indicate inactivity. Most of the special interest groups have been very active in organizing presentations at the national conferences, and 5 of the 13 publish their own newsletters (Table 1). In two cases (Behaviorists for Social Action and Verbal Behavior) those publications have turned into full-fledged journals, and have done so without any financial support from ABA.
Chapters of ABA: Local, State, Regional, and International

Chapters of ABA, like special interest groups, function independently of the central government of ABA. Members of chapters are not necessarily members of ABA. In some of the organizations, well over half of the members also belong to ABA, but in others the percentage may be as low as $10 \%$. Most of the chapters hold conferences at least yearly, and many sponsor other activities, such as symposia, dinners with a speaker, or special topics conferences. At least two have their own affiliate branches which sponsor local meetings. Nearly all of the chapters, at one time or another, have put out newsletters. Some have continued their publications on a regular basis, others publish flyers only when they need to announce upcoming events. A surprising number of chapters are incorporated, a process which entails considerable legal work. Some are politically active and maintain legislative contacts with their state governments. Chapters of $A B A$ vary in size from the Florida Association, with over 600 members, to the newly formed 14-member New York State Association. Outside of the United States, there are 


\section{Table 2}

\section{Council Appointed Committees and Task Forces}

\begin{tabular}{ll}
\hline \multicolumn{1}{c}{ Name } & $\begin{array}{c}\text { Years of } \\
\text { operation }\end{array}$ \\
\hline Program (Convention) & $74-$ \\
Membership & $75-$ \\
Education \& Evaluation & $76-$ \\
Journal & $76-$ \\
Student (formerly “Affiliate”) & $76-$ \\
Professional Development & \\
(formerly “. . of Women") & $76-$ \\
Chicago Involvement & $76-77$ \\
Contributions & $77-77$ \\
Ethics & $76-77$ \\
Contact with Other Organizations & $76-77$ \\
Professional Development of Blacks & $76-78$ \\
International Development & $77-$ \\
Certification & $82-88$ \\
Research Action & $84-$ \\
Public Relations & $85-$ \\
Public Policy & $86-$ \\
Corporate Technology Transfer & $86-$ \\
Right to Effective Education & $86-$ \\
Right to Effective Treatment & $86-88$ \\
Awards & $87-88$ \\
Model Legislation on Treatment & $87-88$ \\
ACDD Standards Review & $89-$ \\
Code of Ethics & $89-$ \\
\hline
\end{tabular}

Note: Data were taken from council records and newsletters, but were not listed here if they were never mentioned in a convention program.

chapters in Belgium, France, Canada, Germany, Ireland, Italy, Japan, Peru, and Uruguay.

Both the special interest groups and chapters of ABA reveal substantial efforts by the membership at a grass roots level. They have moved the organization closer to the goals which it espouses. Much of the success of the conferences, for example, comes from the energy and commitment of individuals working through the grass roots channels of the special interest groups and chapters of the organization.

\section{Committees and Task Forces}

The top-down activities of ABA show in the committees and task forces set up by Council. According to ABA's bylaws, Council appoints chairs of committees and task forces. Chairs, in turn, choose the rest of the committee or task force members, subject to approval by Council. Council funds the task force activities, and the group reports back to Council.

Table 2 shows Council's concerns over the years. The educational emphasis of ABA shows in three of the earliest committees: the Program Committee (responsible for the conference program), the Journal Committee, and the committee called Education and Evaluation. From the beginning, too, Council has been concerned with representation of students and women. It has traditionally taken an advocacy role. For example, early in our history, Council proposed moving the conference out of Chicago because Illinois did not support the ERA, and the membership agreed. More recently, Council has been concerned with the image of behavior analysis (shown in the creation of task forces on Public Relations and Public Policy), with promoting the field outside of academia (Corporate Technology Transfer), and with standards (Code of Ethics and Standards Review).

Special interest groups, chapters, and Council are the main groups within ABA that carry out special functions. The individuals who make up these groups also have professional affiliations with other disciplines. ABA began as a subgroup of the Midwestern Psychological Association, and one issue which appears frequently is ABA's relationship to psychology.

\section{COMPOSITION OF ABA}

In the first presidential address of MABA, Nathan Azrin stated, "What we are witnessing with MABA may be not only a distinctive type of regional convention organization, but also the birth of a new separate discipline; separate from Psychology, Psychiatry, Education, and the other related areas" (Azrin, 1977).

\section{Relationship to Psychology}

The relationship between psychology and behavior analysis has been a complex one. B. F. Skinner, along with Fred Keller and Nat Schoenfeld, although call- 


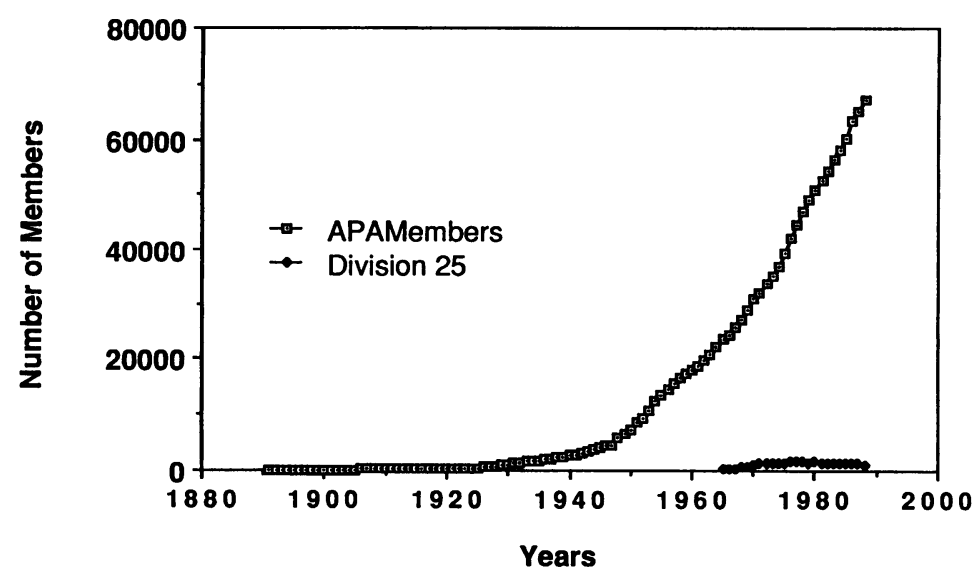

Figure 2. Membership in the American Psychological Association (APA), and in Division 25 of APA.

ing themselves psychologists, took one of the first steps toward separating behavior analysis from psychology by initiating, in the late 1940s, yearly conferences on the experimental analysis of behavior outside of the auspices of the American Psychological Association (APA). The journal that came from those conferences, the Journal of the Experimental Analysis of Behavior, was also set up independently of any psychological organizations. Another major step toward separation was, of course, the founding of this organization. But even as it was founded, MABA showed ambivalence about its relationship to psychology. The original bylaws required one member of Council to be a "nonpsychologist," thus assuming the organization would consist mainly of psychologists while at the same time trying to institutionalize representation of other professionals. (The bylaws now read "Experimental Representative, Applied Representative, and 2 representatives at large.") Our name itself reveals a hesitancy to break completely with psychology. We are not the "Association of Behavior Analysts," but rather "Association FOR Behavior Analysis," thus advocating a field or discipline without implying that behavior analysis is a profession.

If behavior analysis is a branch of psychology, it is a very small branch, more like a twig. Founded in 1892, APA grew slowly at first, taking 48 years to reach the current size of ABA. In the late 1940s, however, membership began to climb steadily to its current 67,000 members. The behavioral part of APA, Division 25 (The Experimental Analysis of Behavior), can barely be seen on a graph of APA membership (Figure 2). Behavior analysts who are also psychologists may fare better in the newly formed American Psychological Society. There, according to the rough guess of several members, 10 to $15 \%$ of the 6,000 members claim a behavioral orientation. Still, $15 \%$ of 6,000 comprises only 750 people, fewer than the numbers in Division 25. Interestingly, ABA's initiation coincided with the beginning of the decline in Division 25's members (see Figure 3). Division 25 might have peaked for other reasons (some of which may have prompted the forming of $\mathrm{ABA}$ in the first place), but it looks as though some psychologists joined ABA instead of APA, rather than joining both organizations.

\section{Representation in Special Education}

Of course, ABA's numbers include professionals who are not psychologists. Of those, most belong to the field of special education. There, too, behavior analysts are a small minority. Since there is no behavioral division of special educators' main organization, The Council for Exceptional Children, it is difficult to say how many members would call themselves behavior analysts. That organization, however, has roughly 55,000 


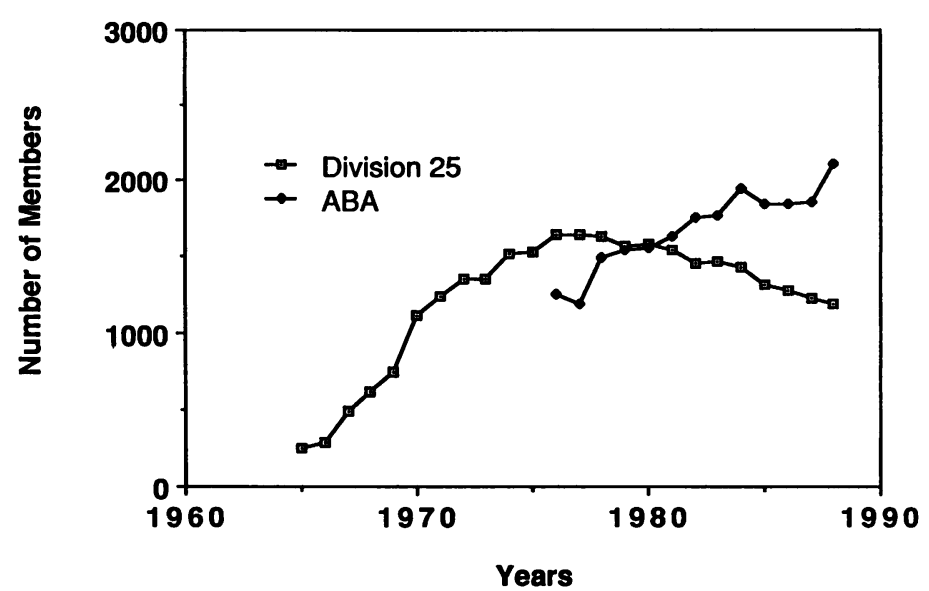

Figure 3. Membership in Division 25 of the American Psychological Association and in the Association for Behavior Analysis (ABA).

members, and it is safe to assume that behavioral members are a small minority.

\section{Composition of $A B A$ 's Membership}

The professional affiliations of ABA members are a bit difficult to tell from ABA's membership database because members are not asked to name their professions. Some rough guesses can be made, however, from the business addresses that most members give as the place they wish to receive mail. Of the full, supporting, and sustaining members with professional affiliations listed, $32 \%$ work within departments I categorized as psychology. (Most were called Psychology, but I also included departments of Human Development and Family Living, Psychiatry, Family Practice, Behavioral Science, Mental Health, and other similar names if they appeared to refer to academic departments rather than clinics or research institutes.) Academic departments within education comprised $11 \%$ of the professional affiliations listed (Figure 4). They included titles such as Educational Research, School/Human Behavior, and Curriculum and Instruction, but by far the majority were departments of special education. Three percent of academics work in other departments, including social work and anthropology. We even have members in philosophy, business, and music. The rest of those giving business addresses, $54 \%$, work in non-academic settings. Most nonacademic members work with special populations, but many work in business and consulting firms, public school settings, research institutes, and state, local, or federal governmental agencies. From the names of the organizations in which members worked, I could not tell what kind of degrees they received, but it is reasonable to assume that most would have master's or doctoral degrees in psychology or special education. The last bar in Figure 4 represents the 334 individuals I could not classify from their address in ABA's database.

If future professional affiliations of members can be judged by current training programs, we will continue to be mainly psychologists and special educators. The recent ABA booklet on Graduate Training in Behavior Analysis includes 40 departments which offer master's or doctoral training in behavior analysis. To qualify as offering a program, a department had to have "an autonomous group of at least three faculty offering a coherent behavioral curriculum" (Critchfield, 1988). A program did not have to have "behavior analysis" in its title or in its description. Of the 40 programs listed, 25 operate within departments of psychology, 9 exist within special education departments, and the 


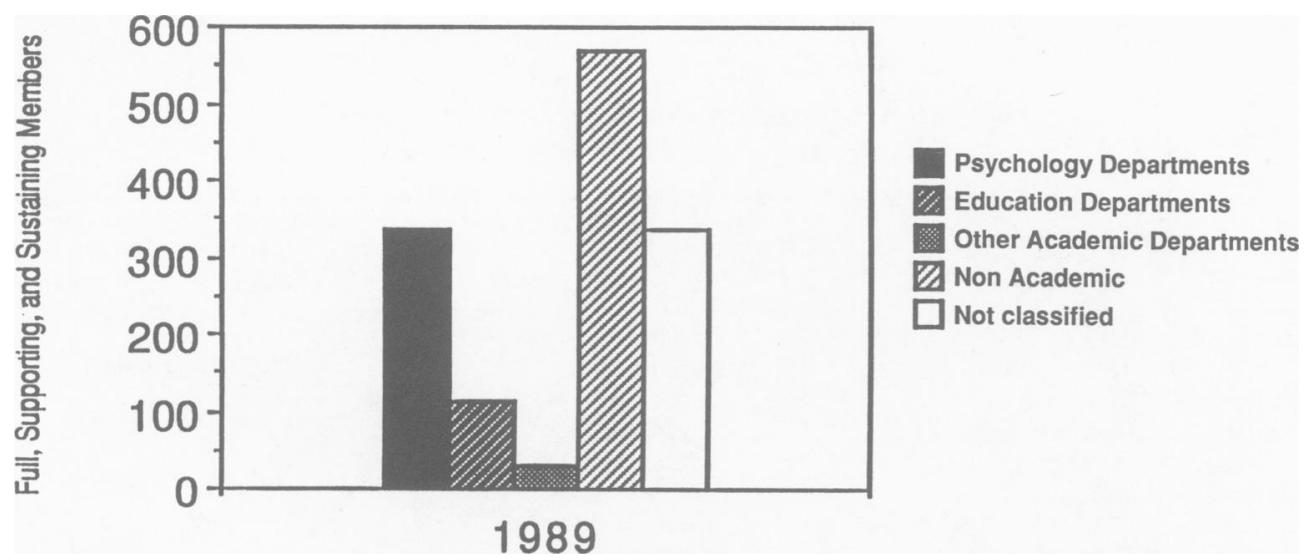

Figure 4. Professional affiliations of full, supporting, and sustaining members of ABA.

rest operate out of departments with other titles (Table 3).

What does calling oneself a behavior analyst mean? Do behavior analysts consider themselves first by their professions-psychologists or educators with a behavior analytic point of view? Or do they consider themselves behavior analysts first, with a specialization in a professional field? I am sure that individuals differ in their answers to those questions, but it is clear that behavior analysts share more than a point of view. We share a subject matter concerned with behavior which emerges during the lifetime of the individual, measured best by frequency of response. We analyze the interactions between the behaving individual and environment within a threeor more-term contingency. We explain behavior through analysis of a history of contingencies of reinforcement which selectively strengthen or weaken particular patterns of responses. Our basic research procedures (whether carried out in the lab or in applied settings) involve repeated measures of behavior over time, typically under different experimental conditions.

Those of us in applied fields share, with our basic researchers, a concern with individual behavior, though many of us also study groups of individuals. Typically, we follow individuals over time, preferring direct daily measures of behavior to questionnaires or interviews or to tests given only once or twice during a treat- ment program or study. Unlike those who explore the psyche and label individuals, we look at the behavior of individuals as a fluid reflection of the contingencies within their lives, and work at changing behavior by altering those contingencies. Those of us in education conceive of our job as changing behavior-helping students experience success. We consider our job not as one of presenting information (with the responsibility for learning left to the student), but rather as one of changing relevant establishing operations, altering stimulus control, or setting up new contingencies of reinforcement until the desired change occurs. When we evaluate, we judge not only the student's behavior, but our own effectiveness. Last, but not least, behavior analysts consider talking, writing, and thinking as verbal behavior rather than as the "use of language."

Though Azrin's hope for a separation of behavior analysis from psychology and education has not been fully realized, behavior analysts can claim a separate discipline or field. The American Heritage Dictionary defines discipline as "a branch of knowledge or of teaching," and field as "an area of human activity or interest; a topic, subject, or area of academic interest or specialization, profession, employment, or business." (American Heritage Dictionary, 1969) We have a discriminable approach to the analysis of behavior, a unique methodology, several journals, and an active international or- 
Table 3

\section{Graduate Training Programs in Behavior Analysis (as listed in ABA's 1988-1989 Directory)}

\begin{tabular}{|c|c|c|c|}
\hline School & Department & $\begin{array}{c}\text { Number } \\
\text { of } \\
\text { students }\end{array}$ & $\begin{array}{c}\text { Behavioral } \\
\text { faculty/ } \\
\text { total faculty }\end{array}$ \\
\hline Auburn University & Psychology & 12 & $8 / 22$ \\
\hline Jacksonville State University & $\begin{array}{l}\text { Psychology } \\
\text { Psychology }\end{array}$ & 25 & $10 / 10$ \\
\hline $\begin{array}{l}\text { University of Alaska } \\
\text { California State-Los Angeles }\end{array}$ & $\begin{array}{l}\text { Psychology } \\
\text { Psychology }\end{array}$ & 15 & $5 / 26$ \\
\hline $\begin{array}{l}\text { California State-Los Angeles } \\
\text { California State-Sacramento }\end{array}$ & $\begin{array}{l}\text { Psychology } \\
\text { Psychology }\end{array}$ & $\begin{array}{l}15 \\
10\end{array}$ & $\begin{array}{l}5 / 26 \\
5 / 25\end{array}$ \\
\hline University of the Pacific & Psychology & 17 & $4 / 7$ \\
\hline University of the Pacific & Special Education & 35 & $2 / 4$ \\
\hline University of Florida & Psychology & 20 & $4 / 33$ \\
\hline University of Hawaii-Manoa & Psychology & 48 & $5 / 25$ \\
\hline DePaul University & Psychology & & $4 / 17$ \\
\hline Southern Illinois University & Rehabilitation Institute & 37 & $6 / 6$ \\
\hline University of Kansas & $\begin{array}{l}\text { Human Development } \\
\text { and Family Life }\end{array}$ & 115 & $21 / 25$ \\
\hline University of Kentucky & Special Education & 39 & $9 / 14$ \\
\hline Louisiana State University & Psychology & 80 & $? / 28$ \\
\hline Northeastern University & Psychology & 20 & $14 / 14$ \\
\hline University of Michigan & Social Work & $?$ & $4 / 51-55$ \\
\hline Western Michigan University & Psychology & 70 & $16 / 22$ \\
\hline Mankato State University & Psychology & 20 & $8 / 20$ \\
\hline St. Cloud State University & Applied Psychology & ? & $6 / 18$ \\
\hline University of Mississippi & Psychology & 49 & $13 / 14$ \\
\hline University of New Hampshire & Psychology & 4 & $4 / 17$ \\
\hline Columbia University Teachers College & Special Education & ? & $1 / 9$ \\
\hline Hofstra University & Psychology & ? & $4 / 26$ \\
\hline $\begin{array}{l}\text { Queens College of the City University of } \\
\text { New York }\end{array}$ & Psychology & 23 & $9 / 40$ \\
\hline State University of New York-Brockport & Psychology & $35-40$ & $? / 15$ \\
\hline State University of New York-Stony Brook & Psychology & New & ?/48 \\
\hline North Dakota State University & Psychology & 15 & $4 / 11$ \\
\hline Kent State University & $\begin{array}{l}\text { Teacher Development } \\
\text { and Curriculum Studies: } \\
\text { Special Education }\end{array}$ & $?$ & $5 / 15$ \\
\hline Ohio State University & Special Education & $?$ & $3 / ?$ \\
\hline University of Oregon & $\begin{array}{l}\text { Counseling \& Educational } \\
\text { Psychology }\end{array}$ & 25 & $4 / 10$ \\
\hline University of Oregon & Special Education & 10 & $3 / 13$ \\
\hline Lehigh University & $\begin{array}{l}\text { Counseling/School } \\
\text { Psychology \& Special } \\
\text { Education }\end{array}$ & 30 & $3 / 3$ \\
\hline University of Texas-Permian Basin & Psychology & 20 & $2 / 4$ \\
\hline Utah State University & Special Education & 20 & $9 / 20$ \\
\hline Central Washington University & Psychology & ? & ?/23 \\
\hline Gonzaga University & Special Education & 30 & $4 / 4$ \\
\hline Washington State Úniversity & Psychology & 10 & $4 / 24$ \\
\hline West Virginia University & Psychology & 46 & $15 / 23$ \\
\hline University of Wisconsin-Oshkosh & Special Education & 100 & $? / 12$ \\
\hline
\end{tabular}

ganization. But we do not yet constitute a profession. Like the field of child development, we work within other professional areas, primarily within psychology and special education, but also within other professional areas.

\section{ABA AND ITS MISSION}

The diversity of ABA, reflected in the differing professions of our members, in the variety of our special interest groups, and in the vigor of our chapters, poses 
no problem for an organization devoted to information exchange through conferences and publications. But it is difficult to represent a diverse membership when taking an advocacy or quality-control role. No one objects if a conference symposium or journal article discusses the need for two semesters on Skinner's Verbal Behavior in the training of behavior analysts, but to make that an association position would divide the membership. Yet ABA is taking and, I think, should take both an advocacy role and a position on standards for training in behavior analysis. We recently voted on the first association position statement, and we are currently working on the accreditation of training programs. The challenge for ABA as an organization will be to set up a mechanism which supports the diverse subgroups of the organization, while drawing upon their expertise and energies to contribute to the development of behavior analysis as a whole.

What ABA needs is coordination between its active groups rather than a strong centralized bureaucracy. I would not go so far in recommending local control as does Morris (1988) in suggesting a federation of autonomous groups, but I would like to see a shift in that direction. $\mathrm{ABA}$ is a volunteer organization. The main reinforcers for volunteering come from having an impact not only outside the organization for which they work, but also within it. Groups who work for the organization, as well as committees and task forces appointed by Council, need to be involved in shaping the direction the organization as a whole takes. Council, in turn, needs feedback directly from those who do the work.

One last point. Some people have expressed concern about the proliferation of behavioral organizations and journals, particularly those formed outside ABA. Organizations such as The Cambridge Center for Behavioral Studies and The International Behaviorology Association have both encountered opposition from within ABA's ranks. Like the diversity within ABA itself, independent efforts outside of our organization also promote the influence of behavior analysis as a whole. I will illustrate my position by analogy.

When I first became a professional and started earning a paycheck, I received a mailing from an organization called "Save the Redwoods." The colorful brochure convinced me to send a few dollars to help preserve our trees. Soon I received a request from the Sierra Club. Wouldn't I help save the wilderness? Yes, I would. Next, I joined Audubon, The Nature Conservancy, and the National Parks and Conservation Society. I felt I should help Save the Whales, prevent the killing of harp seals, protect gorillas, support policing against illegal poaching of elephants for their tusks, rhinos for their horns, or cheetahs for their furs. I have never sent large amounts of money to any of these organizations, but at the end of the year (while filling out income tax forms) I am always amazed at how much money I have actually contributed. Had all of the groups got together and sent one solicitation, I would never have contributed such a sum.

The main resources of professionals is not their money but their time. ABA members working on their own projects in their respective professions or subgroups devote much more time and effort to promoting behavior analysis than they would were they to work only within ABA. Every special interest group, every chapter conference, every journal or newsletter, every behavioral organization and foundation - whether inside or outside of ABA - contributes to the development of our field. Certainly, there are differences between groups in philosophy and approach. But diversity can be a strength, not a weakness. It will be so if we devote our major efforts, not to discrediting behavioral efforts varying from our own, but to promoting behavior analysis within our respective professions, geographical areas, and collegial groups.

Our impact, considering our small numbers, is impressive. Within my area of education, behavioral objectives and competency testing have become commonplace. More explicit behavior analytic work is beginning to appear, too. 
Even nonbehavioral educational research texts (e.g., Borg \& Gall, 1983), are beginning to include major sections on "single-subject research designs," complete with sample studies from JABA. At the other end of the age range, behavioral terminology is beginning to enter licensing standards for day care centers. The 1988 revision of the Alaska Child Care Facilities Regulations replaced a section on punishment with a section that contains the statement, "Discipline and behavior management policies must provide for positive reinforcement, redirection, and setting of clear and consistent limits" (Alaska, 1988, p. 25). If current trends continue, hundreds of thousands of children could benefit from the effective and humane practices drawn from our science. Clearly large numbers of ABA members are not needed for large impacts.

We are a small minority, but we have accomplished much within our respective professions. Ours is a road less traveled. But we have already made a difference, we are making a difference and, in a world beset by problems, we must make a difference. For it is our science which,
I believe, provides most hope for the future.

\section{REFERENCES}

Alaska child care facilities regulations. (1988). Juneau, AK: Department of Health and Social Services.

The American heritage dictionary of the English language. (1969). New York: American Heritage.

Azrin, N. (1977). Past president's message. The MABA Newsletter, 1, No. $1,1$.

Borg, W. R., \& Gall, M. D. (1983). Educational research: An introduction (4th ed.). New York: Longman.

Critchfield, T.(Ed.). (1988-89). Graduate training in behavior analysis. Kalamazoo, MI: Association for Behavior Analysis.

Etzel, B. (1987). Message from the president. The $A B A$ Newsletter, 10, No. 2, 2.

Etzel, B. (1988). Message from the president: Is an intervention called for? The ABA Newsletter, 11 , No. 1, 2-5.

Frost, R. (1971). The road not taken. In E. C. Lathem (Ed.), The Poetry of Robert Frost (p. 105). Barre, MA: Imprint Society. (Original work published 1916)

Morris, E. K. (1988). A federation from within. The ABA Newsletter, 11, No. 3, 7 .

Peterson, M. E. (1978). The midwestern association of behavior analysis: Past, present, future. The Behavior Analyst, 1, 3-15. 